\title{
The Strategic Management and the Illegality: a case study on the fighting against piracy in Brazil
}

\author{
A Gestão Estratégica e a Ilegalidade: um estudo de caso do combate à pirataria \\ no Brasil
}
La Gestión Estratégica y la Ilegalidad: un estudio de caso del combate a la piratería en Brasil

Received on June 18, 2012 / Approved on April 2, 2013

Responsible Editor: João Maurício Gama Boaventura, Dr.

Evaluation process: Double Blind Review

\begin{abstract}
Multinational companies that suffer from the impact of piracy must recognize the important social and political differences between the local market and the international market to formulate their integrated market and nonmarket strategies. Little is known about the extent to which piracy affects the processes of strategic management of multinational companies operating in emerging countries, where institutional failures restrict the market, or about the type of nonmarket activities used by these companies to achieve their goals of political action. To study this phenomenon, three multinational pharmaceutical companies suffering from illegality were investigated. The evidences of the survey showed that there is
\end{abstract}

a global strategic integration - market and nonmarket (BARON, 1995a). The companies that suffer from piracy tend to use a geocentric structure (PELMUTTER, 1969) formulating nonmarket centralized strategies with the support of specialists to maximize resources. Locally, the subsidiaries implement the global nonmarket strategies, choosing to perform collective activities - independently of the amount of resources available (HILMANN; HITT, 1999).

Keywords: Nonmarket strategy. Integrated strategy. Piracy. Geocentric structure. Collective action.

1. Master in Strategy from Getúlio Vargas Foundation (FGV). [solange@amcham.com.br]

2. Doctor in Production Engineering from the Federal University of Santa Catarina (UFSC). Professor at Getúlio Vargas Foundation (FGV). [rodrigo.bandeira.demello@fgv.br]

Authors' address: Av. 9 de Julho, 2029 - Bela Vista, São Paulo - SP CEP. 01313-902 - Brazil 


\section{RESUMO}

As empresas multinacionais que sofrem com o impacto da pirataria precisam reconhecer as importantes diferenças sociais e políticas existentes entre o mercado local e o mercado internacional para formular estratégias de mercado e não mercado integradas, que sejam eficazes no combate dos produtos piratas. Pouco se sabe sobre a extensão em que a pirataria afeta os processos de gestão estratégica das empresas multinacionais que atuam em países emergentes, onde as falhas institucionais restringem o mercado, e nem tampouco se conhece a estrutura organizacional que suporta estas atividades e os tipos de atividades de não mercado escolhidas para atingir os seus objetivos de ação política. Para estudar este fenômeno foram pesquisadas três empresas multinacionais do setor farmacêutico fabricantes de medicamentos de disfunção erétil que sofrem com a ilegalidade. As evidências da pesquisa mostram que a integração estratégica mercado e não mercado - só ocorre globalmente (BARON, 1995a). As empresas que sofrem maior impacto com a pirataria se organizam com uma estrutura geocêntrica (PELMUTTER, 1969) com a formulação de estratégias de não mercado global feitas por especialistas para maximizar recursos. Localmente, as subsidiárias implementam as estratégias globais e optam pelas açóes coletivas independente dos recursos disponíveis (HILMANN; HITT, 1999) por meio do fortalecimento das instituiçôes de classe.

Palavras-chave: Estratégia de não mercado. Estratégia integrada. Pirataria. Estrutura geocêntrica. Açóes coletivas.

\section{RESUMEN}

Las empresas multinacionales que sufren el impacto de la piratería deben reconocer las importantes diferencias sociales y políticas entre el mercado local y el mercado internacional para desarrollar estrategias integradas de mercado y no mercado eficaces en la lucha contra los productos piratas. Poco se sabe sobre el grado en que la piratería afecta a los procesos de gestión estratégica de las empresas multinacionales que operan en los países emergentes, donde los fallos institucionales limitan el mercado, ni tampoco la estructura organizacional que apoya estas actividades y los tipos de actividades elegidas para lograr sus objetivos de acción política. Para estudiar este fenómeno, han sido investigados tres fabricantes multinacionales de medicamentos de disfunción eréctil afectados por la ilegalidad. La evidencia de la investigación muestra que la integración estratégica - de mercado y de no mercado sólo se produce a nivel mundial (BARON, 1995a). Las empresas que sufren el mayor impacto de la piratería se organizan mediante una estructura geocéntrica (PELMUTTER, 1969) con estrategias globales centralizadas realizadas por expertos para aprovechar al máximo los recursos. Las filiales locales ponen en práctica estrategias globales y optan por las acciones colectivas independientes de los recursos disponibles (HILLMAN; HITT, 1999) mediante el fortalecimiento de las instituciones de la clase.

Palabras clave: Estrategia de no mercado. Estrategia integrada. Piratería. Estructura geocéntrica. Acciones colectivas.

\section{INTRODUCTION}

Companies suffering from piracy are challenged to develop nonmarket strategies to minimize the noxious effects of their market reduction, or to defend themselves from possible problems to their institutional image, due to the utilization of phony products. With that, multinational companies have an additional challenge, because they need to recognize the important social and political differences existing between the local market and the international one, to design their nonmarket strategies. Thus, they need to achieve the integration of market strategies and nonmarket strategies to get sustainable competitive advantages. Little is known about the extent to which piracy affects the processes of strategic management of multinational companies operating in emerging countries, where institutional failures restrict the 
market, or about the type of nonmarket activities used by these companies to achieve their goals of political action (HILLMAN; HITT, 1999).

According to Baron (1995a), in defining their strategies, companies should have both their market and nonmarket areas working integrated to defend the global interests of the company in regard to piracy. The researched articles addressing the nonmarket strategies theme and how companies face the challenges in emerging markets analyze the differences in strategies, or differences per sector or per country, in order to identify the patters that are developed as a proposal (RUFIN; PARADA; SERRA, 2008).

Published articles addressing piracy and its impacts focus on legal issues versus the legislation in force in the USA (MILLER; BOVE, 2009), discuss piracy from the behavioral viewpoint (IYENGAR et al., 2008; SINHA; MACHADO; SELLMAN, 2010; WOOLLEY, 2010), or study models with suggestions of strategic actions to minimize the effects of piracy on software, music and movies (GOPAL; LERTWACHARA; MARSDEN, 2006; KARIITHI, 2011; SMITH; TELANG, 2009; YANG et al., 2009). Another approach also found in the articles researched was of specific studies on industrial sectors such as the study of Lagreca and Hexsel (2007) on the tobacco sector, and the study of Giglio and Ryngelblum (2009) with a view on the fighting strategies using social networks.

In this study, we analyze how occurs the strategic management process of multinational companies of the pharmaceutical industry erectile dysfunction medicine makers - which operate in the Brazilian market and suffer from the impact of piracy, evaluating whether such companies integrate their market and nonmarket strategies to fight piracy, and what are the main nonmarket activities used by these companies in the domestic market.

According to the National Agency of Sanitary Surveillance (ANVISA, 2010), piracy in the field of medicines is a set of illegal activities encompassing falsification, adulteration, smuggling (criminal nonpayment of customs duty), robbery of cargo, and trading products with no registration or in poor use conditions, and in the past three years, approximately $80 \%$ of counterfeited medicine apprehensions in Brazil were composed of erectile dysfunction medicines. According to the survey conducted by the World Health Organization (WHO, 2006), the global tax losses resulting from medicine piracy is approximately US\$35 billion.

The urgency of effective strategies is crucial in the specific case of piracy, because this is a relatively new phenomenon, growing in the globalized world with a destructive impact on the institutional and financial reputation of companies due to the harms caused by drugs or placebos used in phony medicines to the health of their users.

The main results obtained along with a deeper discussion on the implications of such results in Brazilian subsidiaries are presented as follows. Such results were based on the theoretical referential presented in the following section.

\section{THEORETICAL REFERENTIAL}

The theoretical basis providing references to the research is centered on the integration of market and nonmarket strategies (BARON, 1995a), on the model of approach, participation and strategic decision-making for the nonmarket (HILLMAN; HITT, 1999), and on the structure in regard to the parent company/subsidiary used by Perlmutter (1969), and Bartlett and Ghoshal (1989).

\section{I Market and nonmarket integrated strategies}

Companies suffering from the impact of piracy are exposed to institutional failures that restrict their market, and need to develop strategies to influence the institutional environment composed of governmental institutions in the executive, legislative and judiciary powers. Uncertainties influence the decision of individuals and the strategies of companies (NORTH, 1990). With the globalization process (MAHONEY; CHI, 2001 (before 2008)), international 
companies are facing a scenario different from that they were used to. The existing business environment in the parent company is not the same as of the emerging countries. Uncertainties vary from country to country (KHANNA; PALEPU, 2000 (before 1999)), and in the emerging countries there is a great variety of market failures - such as the low inspection level and the low rate of punishments provided by the current legislation - which ends up creating favoring opportunities. Lagreca and Hexsel (2007) confirm that (KHANNA; PALEPU, 2000 (before 1999)) with the study on the impacts of disloyal competition in Brazil in the cigarette industry, by understanding the dynamics of relations between the company and the institutions. Although the authors do not explore the intrinsic nature of strategies elaborated by this industry companies, they analyze the external factors affecting the competitiveness of the industry because of institutional failures.

Ryngelblum (2007), in his study on piracy in Brazil, suggests that is necessary to work with governmental institutions in four main fronts: (I) inspection and repression by shutting up factories, shops and selling malls, as well as apprehension of products; (II) lobby with legislators and rulers aiming to reduce taxes; (III) advertisement campaigns, sometimes alerting consumers about pirate products, other times threatening them with punishments; (IV) development of instruments more powerful than the current instruments of legitimacy of antipiracy efforts, associated to the creation of alternative job opportunities for the people that currently depends economically on such kind of work.

The expression nonmarket strategy was popularized by Baron in a series of articles published between 1995 and 1999. The nonmarket environment is formed of social, political and legal arrangements that structure the interactions between companies and individuals, interest groups, governmental institutions and the public, and which is not intermediated by the market, but rather by public and private institutions, being characterized by issues, institutions, interests and information (BODDEWYN, 2003).
Boddewyn and Brewer (1994) explore the difficulties found by international companies when developing their nonmarket strategies in countries with singular and different characteristics in comparison with their origin countries. The political behavior of international companies simultaneously suffers from the type of company (international, multinational, transactional, domestic, importer, exporter), of the industry, and of the nonmarket context. This means that companies investing in other countries should not merely develop supplementary or alternative strategies allied to their economic strategies, but they should rather study various existing idiosyncrasies that interfere and impact the allocation of scarce resources.

To be effective, a company needs to integrate market and nonmarket strategies, adjusting them to its environment and to its competences (BARON, 1995a). There is a substantial interdependency between the company competitiveness and the government policies (BARON, 1995a), which makes critical to companies to develop political strategies as part of their general strategy (BARON, 1995a) If the government is important for the future competitiveness of the company, the political action needs to be a business priority (YOFFIE, 1987). In case of piracy, companies need to develop political strategies aiming to minimize the institutional failures that are mainly centered on inspection and a more punitive legislation, in addition to help in the process of people awareness about the harms of piracy that is connected to the international crime.

\subsection{Model of approach, participation and strategic decision-making for the nonmarket}

By means of the political behavior, companies can potentially increase the size of their market and have a competitive edge. With that, they reduce the threat of the inflow of substitutes, and increase the bargain power in relation to suppliers and consumers (HILLMAN; HITT, 1999). Companies need to be proactive to achieve the potential goals and benefits of the political 
behavior (KEIM, 1981). For such a purpose, they formulate their strategies within three dimensions of political strategy (HILLMAN; HITT, 1999): 1) approaches for political strategies; 2) levels of participation; 3) types of strategies.

In addition to the aforementioned dimensions, Hillman and Hitt (1999) name the institutional relationship of such strategies as transactional and relational. The transactional relationship takes place when a strategy is formulated in response to a specific political issue, and has a relatively short duration. The relational relationship is of long term, with the aim of creating a more lasting relationship with the institutions, and covers various issues simultaneously, in such a way that the developed contacts and resources might be used as soon as new issues arise.

The main variables affecting the companies' decisions on selecting either a transactional or relational relationship are: 1) the degree in which the company is affected by the public policy; 2) the level of the product diversification; 3) the degree of corporatism/pluralism within the country in which the companies operate (HILLMAN; HITT, 1999).

Hillman and Hitt (1999) propose:

a) companies more dependent on governmental policies tend to more likely use the relational approach;

b) companies with more financial resources and/or intangible resources, such as, for instance, knowledge of political influence, tend to more likely use the independent individual participation of the selected approach;

c) companies with lesser financial resources and/or intangible resources, such as, for instance, knowledge of political influence, tend to more likely use the independent collective participation of the selected approach;

d) companies or associations tend to more likely use the strategy of providing information or financial incentive if they have selected a transactional approach, and the issue is at the formulation stage;

e) companies and associations with high credibility tend to more likely use the strategy of providing information or formation of voters' basis, provided that they have selected a relational approach.

As for the levels of participation, the companies select: 1) collective actions, or 2) individual actions, and the determining factor for this selection is the value of the resources available for their political actions (HILLMAN; HITT, 1999). Collective actions designed to act in the nonmarket environment are generally permitted by the legislation, and, therefore, companies decide to act in a joint manner through professional coalitions or associations. Thus, companies can save and jointly create political actions to defend themselves from the public policies.

Companies can also configure their competences by developing them internally or contracting them externally, such as, for instance, for the legal, public relation, governmental relation, and political advice areas (HILLMAN; HITT, 1999). Instead of each company monitoring and influencing the political processes individually, via business association, they can create a scale economy, increasing the knowledge about the issue, and creating synergies or other intangible resources through the integration of the collective knowledge.

\subsection{Structure and organization in multinational companies (EMNs)}

Mariotto (2007) presents the EMNs multinational companies - in terms of structure in regard to the parent company/subsidiary, according to Perlmutter (1969), as: ethnocentric, polycentric and geocentric. In the ethnocentric one, values and standards are the same as in the parent company, and they are imposed to the subsidiaries, while in the polycentric one, the cultures of host countries are respected, and the subsidiary shall have its local identity. In the third type of orientation, the geocentric one, the subsidiary contributes to the parent company with new skills and knowledge of advanced technology.

As geocentric, the EMN internalizes the exploitation of comparative advantages of each country in which it operates, keeping a hierarchical 
structure, in which the parent company coordinates the activities of all international operations. The creation of strategies would be unilateral, from the parent company to the subsidiaries in order to explore the competitive advantages coming from the parent company itself.

Bartlett and Ghoshal (1989) define that, to become international, companies should adopt market strategies such as: transactional, global and multi-domestic. Transactional strategies are centered on transferring the knowledge of corporate areas to foreign markets. Global strategies are those in which products and strategies are developed to explore and integrated the worldwide market in a uniform way. Harzing (2000) defines the global company with integrated operations and a structure similar to a hub and spoke, different from the transactional company that does not have the parent company in a dominant role. Subsidiaries can be specialized strategic centers for a certain process.

Transactional and global nonmarket strategies do not seem to be as successful as the market strategies, according to Bartlett and Goshal (1989), because they need to take into consideration the institutions, political issues and configurations existing in the countries where they are located. Many nonmarket issues have a strong domestic orientation, and are more likely to have multidomestic strategies than the market issues. The success of the implementation of nonmarket multidomestic strategies involves specific action plans that are developed according to the institutions and individual interests of each country.

\subsection{Propositions of the research}

There are three propositions arising from the studied theory, and which were the focus of the research conducted:

1. PROPOSITION 1: To be successful in fighting piracy, the company needs to formulate integrated market and nonmarket strategies (BARON, 1995a).

2. PROPOSITION 2: The polycentric parent company/subsidiary structure (PERLMUTTER, 1969) would be the structure chosen by the EMNs, because the cultures of host countries are respected, and the subsidiary defines its own strategies according to the local idiosyncrasies.

3. PROPOSITION 3: EMNs locally structure their political actions, by choosing relational, collective approaches, centered on the provision of information, and that, according to Ryngelblum (2007), are centered on the following areas: (I) inspection and repression; (II) lobby with legislators and rulers; (III) advertisement campaigns, sometimes alerting consumers about pirate products, other times threatening them with punishments; (IV) development of instruments associated to the creation of alternative job opportunities for the people that currently depends economically on such kind of work.

\section{METHOD}

The methodology chosen was the descriptive analytical case study, due to the fact that the theme of piracy is complex, with few empirical studies available that can be the study basis, and with insufficient data available for a statistical comparison. The information available is restricted to what is published by the journalistic media, or become public through governmental institutions that only report what is apprehended by the police authorities.

\section{I Data sources and collection}

To check the transformations and adjustments made to globalized strategies of multinational companies makers of medicines for erectile dysfunction, three major multinational laboratories where chosen in Brazil, makers of such drugs. Two of them, hereinafter referred to as Company A and Company C, have US capital, and one has European capital, and is hereinafter referred to as Company B. All together, they share approximately $90 \%$ of the Brazilian market of erectile dysfunction drugs.

Semi-structured interviews were conducted with the three multinational companies, with 
the main aim of understanding the integration model used to formulate market and nonmarket strategies, and the operationalization of strategies regarding piracy. The interviews resulted in approximately four hours of recording, and for more specific information, emails were exchanged, allowing to deepening some issues arisen in the research.

In Chart 1, the profile of interviewers and the type of contact made with the companies are presented. In addition to direct interviews with the three companies, other two pharmaceutical companies were visited many times, to triangulate the information on global strategies, the structure supporting global strategies, and the selection of political actions: a Covidien (Governmental Relations Officer), a pharmaceutical maker of medical equipment, and Merck Sharp and Dome (Governmental Relations Officer).

\begin{tabular}{|c|c|c|c|c|}
\hline $\begin{array}{l}\text { Company } \\
\text { name }\end{array}$ & Manner of contact & $\begin{array}{c}\text { Duration of } \\
\text { interview }\end{array}$ & $\begin{array}{l}\text { Number of } \\
\text { contacts }\end{array}$ & Information obtained \\
\hline \multirow[t]{2}{*}{ Company A } & $\begin{array}{l}\text { Interview recorded } \\
\text { with the corporate vice- } \\
\text { president and the quality } \\
\text { manager }\end{array}$ & 1 hour & 4 & $\begin{array}{l}\text { Current situation of the piracy impact, } \\
\text { repression activities, outsourcing, utilization } \\
\text { of business association and relationship with } \\
\text { the government }\end{array}$ \\
\hline & $\begin{array}{l}\text { E-mails exchanged with } \\
\text { the quality manager }\end{array}$ & & 10 & Corporate structure at the parent company \\
\hline \multirow[t]{2}{*}{ Company C } & $\begin{array}{l}\text { Interview recorded } \\
\text { with the security area } \\
\text { coordinator, legal officer } \\
\text { and legal advisor }\end{array}$ & $\begin{array}{l}1 \text { hour and } \\
30 \mathrm{~min} \text {. }\end{array}$ & 2 & $\begin{array}{l}\text { Current situation of the piracy impact, } \\
\text { repression activities, outsourcing, utilization } \\
\text { of business association and relationship with } \\
\text { the government }\end{array}$ \\
\hline & E-mails & & 5 & $\begin{array}{l}\text { Further explanations about apprehensions, } \\
\text { contacts with governmental bodies, contact } \\
\text { with business association }\end{array}$ \\
\hline \multirow[t]{2}{*}{ Company B } & $\begin{array}{l}\text { Interview recorded with } \\
\text { the corporate matters } \\
\text { officer }\end{array}$ & 2 hours & 2 & $\begin{array}{l}\text { Current situation of the piracy impact, } \\
\text { repression activities, outsourcing, utilization } \\
\text { of business association and relationship with } \\
\text { the government }\end{array}$ \\
\hline & E-mails & & 5 & Contacts with ETCO and Federal Revenue \\
\hline \multirow[t]{2}{*}{ Covidien } & $\begin{array}{l}\text { Interview recorded with } \\
\text { the corporate matters } \\
\text { officer }\end{array}$ & 2 hours & 1 & $\begin{array}{l}\text { Track records of the pharmaceutical industry, } \\
\text { main impacts of illegality, process of } \\
\text { relationship with the Government, laws and } \\
\text { regulations, AIDS program }\end{array}$ \\
\hline & E-mails & & 3 & Contacts and presentation with Company B \\
\hline Merck & $\begin{array}{l}\text { Interview with the legal } \\
\text { officer }\end{array}$ & 2 hours & 2 & $\begin{array}{l}\text { Main impacts of illegality, process of } \\
\text { relationship with the Government, laws and } \\
\text { regulations }\end{array}$ \\
\hline
\end{tabular}

CHART 1 - List of companies taking part of the research

Source: the author.

After the first research phase, the information collected - specified in Chart 1 were checked in various inspection bodies of the medicine sector - specified in Chart 2 - as follows: National Agency of Sanitary Surveillance (ANVISA), National Council of Fight against Piracy and Crimes against the Intellectual Property (CNCP), Ministry of Justice, National Forum of Fight against Piracy and Illegality (FNCP),
Association of the Research Pharmaceutical Industry (Interfarma), Brazilian Association of Intellectual Property (ABPI), Federation of Industries of São Paulo State (FIESP) (Intellectual Brazil Coalition), Danneman \& Simensen - law firm specialized in intellectual property with registered office in Rio de Janeiro, and an office in São Paulo, US Chamber of Commerce - Brazil US Business Council in Washington, DC, USA. 


\begin{tabular}{|c|c|c|c|}
\hline $\begin{array}{l}\text { Name of the } \\
\text { institution }\end{array}$ & Manner of contact & $\begin{array}{l}\text { Number of } \\
\text { contacts }\end{array}$ & Information obtained \\
\hline \multirow[t]{2}{*}{$\begin{array}{l}\text { FIESP - Federation of } \\
\text { the Industries of São } \\
\text { Paulo State }\end{array}$} & $\begin{array}{l}\text { Meeting with DEREX } \\
\text { manager and the } \\
\text { Commercial Defense } \\
\text { coordinator }\end{array}$ & 4 & $\begin{array}{l}\text { Piracy fighting programs, report "Dialogue with Public } \\
\text { Servants", textbook: "Brazil Intellectual: a positive } \\
\text { agenda", information about medicine apprehensions, } \\
\text { training program of federal agents in ports and airports }\end{array}$ \\
\hline & E-mails & 20 & Information on programs and training attendance. \\
\hline \multirow[t]{2}{*}{$\begin{array}{l}\text { ABPI - Brazilian } \\
\text { Association of } \\
\text { Intellectual Property }\end{array}$} & $\begin{array}{l}\text { Interview with the } \\
\text { executive officer }\end{array}$ & 3 & $\begin{array}{l}\text { Programs developed by the entity to fight piracy, } \\
\text { participation in the CNCP, main issues discussed by } \\
\text { pharmaceutical companies, "International Congress of } \\
\text { Intellectual Property", and obtainment of clipping for } \\
\text { consultation. }\end{array}$ \\
\hline & E-mails & 5 & $\begin{array}{l}\text { Information on clippings and lecturers of the } 2010 \text { and } \\
2011 \text { Congresses. }\end{array}$ \\
\hline \multirow[t]{2}{*}{ Interfarma } & $\begin{array}{l}\text { Interview with the } \\
\text { legal officer }\end{array}$ & 2 & $\begin{array}{l}\text { Programs developed by the entity to fight piracy, } \\
\text { main issues discussed by pharmaceutical companies, } \\
\text { committee of piracy fighting and main topics, } \\
\text { apprehension actions and programs of relationship } \\
\text { with the Executive, Legislative and Judiciary powers. }\end{array}$ \\
\hline & E-mails & 5 & $\begin{array}{l}\text { Information on contacts at pharmaceutical companies, } \\
\text { and information on dates and participation in the } \\
\text { piracy fighting committee. }\end{array}$ \\
\hline \multirow[t]{2}{*}{$\begin{array}{l}\text { FNCP - National } \\
\text { Forum of Piracy } \\
\text { Fighting }\end{array}$} & $\begin{array}{l}\text { Interview with the } \\
\text { executive officer }\end{array}$ & 2 & $\begin{array}{l}\text { Programs developed by the entity to fight piracy, } \\
\text { participation in the CNCP, Brazilian legislation } \\
\text { and its failures, main issues regarding inspection, } \\
\text { apprehension and losses, issues discussed in the } \\
\text { management of the Association, relationship with } \\
\text { Federal Revenue and polices. }\end{array}$ \\
\hline & E-mails & 2 & $\begin{array}{l}\text { Participation in the management meeting and minutes } \\
\text { of meetings. }\end{array}$ \\
\hline \multirow[t]{2}{*}{$\begin{array}{l}\text { CNCP - National } \\
\text { Council of Piracy } \\
\text { Fighting }\end{array}$} & $\begin{array}{l}\text { Meeting with the } \\
\text { executive secretary of } \\
\text { the CNCP }\end{array}$ & 1 & $\begin{array}{l}\text { Participation in the CNCP meeting to organize a } \\
\text { databank with information and tips about pirate } \\
\text { products. }\end{array}$ \\
\hline & E-mails & 4 & \\
\hline \multirow[t]{2}{*}{$\begin{array}{l}\text { US Chamber of } \\
\text { Commerce - Brazil } \\
\text { US Business Council } \\
\text { - Washington - DC }\end{array}$} & $\begin{array}{c}\text { Meeting in } \\
\text { Washington with the } \\
\text { executive officer of } \\
\text { Brazil US Business } \\
\text { Council and its } \\
\text { members of the } \\
\text { pharmaceutical } \\
\text { industry }\end{array}$ & 1 & $\begin{array}{l}\text { Participation in the annual Planning meeting of } \\
\text { the Brazil US Business Council, in which the topic } \\
\text { "Intellectual Property" was addressed and discussed } \\
\text { among the members of the Pharmaceutical Industry. }\end{array}$ \\
\hline & E-mails & 1 & $\begin{array}{l}\text { Exchange of e-mails for information on investigation } \\
\text { actions in Latin America, and international figures on } \\
\text { medicine piracy. }\end{array}$ \\
\hline $\begin{array}{l}\text { ANVISA - National } \\
\text { Agency of Sanitary } \\
\text { Surveillance }\end{array}$ & E-mails & 2 & $\begin{array}{l}\text { Request of information on erectile dysfunction } \\
\text { medicine apprehensions in Brazil, and existing } \\
\text { agreements for information exchange with neighbor } \\
\text { countries. }\end{array}$ \\
\hline $\begin{array}{l}\text { Dannemann } \\
\text { Siemensen - Rio de } \\
\text { Janeiro and São Paulo }\end{array}$ & $\begin{array}{l}\text { Interview with the } \\
\text { senior partner of the } \\
\text { Piracy and Intellectual } \\
\text { Property area. }\end{array}$ & 2 & $\begin{array}{l}\text { Contacts with the industry's companies, fighting } \\
\text { actions, process of outsourcing of repression actions, } \\
\text { main apprehension. }\end{array}$ \\
\hline
\end{tabular}

CHART 2 - List of governmental associations and institutions involved in the research.

Source: the author. 
The triangulation of information was conducted in three stages: 1) verification of the existence and participation of the laboratories in the mentioned activities, through visits to the government or professional entities. In such visits, the records of participation in meetings, and the themes and discussions conducted were checked; 2) verification of information of medicine apprehensions at ANVISA. Only information confirmed for more than one source was considered in the research. ABPI news clipping on the topic intellectual property was used to get information about medicine apprehensions, about the reputation, security expenses and nonmarket activities used by the companies. Major newspapers were prioritized, although some articles of the magazine Veja were selected because of the deeper discussion the magazine did about the topic medicine piracy. During the work, newspaper reports published about medicine piracy from January 27, 2009, to March 30, 2011, were researched and selected - approximately 490 electronic newsletters were researched; 3) the corporate structure and the outsourcing were the last part of the triangulation. The visit to the US Chamber of Commerce in the United States Washington - helped us understanding how one of the researched companies was structured, and how international professional entities take part in the process. Chart 2 presents the list of researched institutions and the type of information obtained from each of them.

\section{RESULTS}

The research results were compared with the theoretical models according to three approaches: 1) integration of nonmarket and market strategies; 2) corporate structure for the nonmarket strategies; and 3) nonmarket activities.

\section{I Integration of nonmarket and market strategies}

The analysis of information on the strategies integration was done using the following criterion:

1. To be effective, the company needs to consider the components of the market and of the nonmarket (BARON, 1995a), formulating integrated market and nonmarket strategies. The evidence of integration was related to:

a. Existence of frequent meetings with the work committee or group, involving the market and nonmarket areas;

b. Nonmarket strategies discussed in the local management meeting with the presence of market and nonmarket areas.

\begin{tabular}{|c|c|c|c|c|}
\hline & & Company A & Company B & Company C \\
\hline \multirow[t]{2}{*}{$\begin{array}{l}\text { Market and nonmarket } \\
\text { strategies integration }\end{array}$} & $\begin{array}{c}\text { Frequent meetings with } \\
\text { work committee or group, } \\
\text { involving market and } \\
\text { nonmarket areas }\end{array}$ & $\begin{array}{l}\text { Sporadic } \\
\text { meetings }\end{array}$ & $\begin{array}{l}\text { Meetings only } \\
\text { take place when } \\
\text { there is an } \\
\text { occurrence }\end{array}$ & Sporadic meetings \\
\hline & $\begin{array}{l}\text { Nonmarket strategies } \\
\text { discussed in the meeting of } \\
\text { the local management, with } \\
\text { the presence of the market } \\
\text { and nonmarket areas. }\end{array}$ & $\begin{array}{c}\text { There were no } \\
\text { evidences }\end{array}$ & $\begin{array}{l}\text { There were no } \\
\text { evidences }\end{array}$ & $\begin{array}{l}\text { There were no } \\
\text { evidences }\end{array}$ \\
\hline
\end{tabular}

CHART 3 - Analysis of data obtained for the strategies integration

Source: adapted from Baron (1995a).

In the three companies researched there were no evidences of integration of market and nonmarket strategies in Brazil. Issues regarding piracy are confidential, and are not discussed in the management meetings, and the existence of frequent meetings of work groups or committees to integrate activities was also not found. In Company A, up until the end of 2010, there was 
a small committee in Brazil that integrated the market and nonmarket areas, and which had the capacity of locally proposing and defining strategies. However, this situation completely changed, since the company has internationally defined that the priority would be to maximize the use of resources and preserve the personal security of its collaborators. In company $\mathrm{C}$, the local corporate security area has little interaction with the market areas, because its main function is the investigation. Market areas are used to collect information that are then sent to the international team centralized in the parent company. In Company $\mathrm{B}$, there is the Global Anti-falsification Work (GTAF), local, which is responsible for the piracy fighting strategies and actions, and which integrates the market and nonmarket areas. However, as there are few incidents in Brazil, GTAF activities are few, and the group meeting are sporadic.

The International Legal area coordinates the piracy issue internationally, because it involves the issues of legality, security and intellectual property, which are the scope of the company's legal sector.

The legal dept. provides legal support regarding security. Who gives such support is the legal area. The strategic area of the product is the one providing guidelines for all departments. A product being counterfeited in Paraguay does not reflect on the loss, but the policy of Company B is clear saying it has to be fought. The parent company is clear and determines that the Legal dept. is responsible for that. (Interview with the person responsible for the Security Dept. of Company B, 2010). ${ }^{1}$

In Chart 4, the strategic processes of researched companies are summarized. The existence of an international group responsible for the strategic formulation of the piracy fighting area was found, and such group reports to the corporation tax/legal area.

\begin{tabular}{|l|c|c|c|}
\hline $\begin{array}{l}\text { Market and nonmarket } \\
\text { strategies integration }\end{array}$ & Company A & Company B & Company C \\
\hline Integration of strategies & Occurs internationally & Occurs internationally & Occurs internationally \\
\hline $\begin{array}{l}\text { Definition of strategy and } \\
\text { local integration }\end{array}$ & $\begin{array}{c}\text { Up until 2010, it was local, } \\
\text { only now it is international }\end{array}$ & $\begin{array}{c}\text { It does not occur, } \\
\text { connected to investigation }\end{array}$ & $\begin{array}{c}\text { Local GTAF that follows } \\
\text { international Norma 70 }\end{array}$ \\
\hline International team & $\begin{array}{c}\text { International team } \\
\text { specialized in piracy }\end{array}$ & $\begin{array}{c}\text { International team } \\
\text { specialized in security }\end{array}$ & $\begin{array}{c}\text { International team } \\
\text { specialized in falsification }\end{array}$ \\
\hline $\begin{array}{l}\text { Reporting from the } \\
\text { international team within the } \\
\text { International organization }\end{array}$ & $\begin{array}{c}\text { International Corporate } \\
\text { Relations - Political VP }\end{array}$ & $\begin{array}{c}\text { Global Corporate Security } \\
\text { - Global Legal Area }\end{array}$ & $\begin{array}{c}\text { Global Legal Area - Laws } \\
\text { and Patents }\end{array}$ \\
\hline
\end{tabular}

CHART 4 - Integration of $\mathrm{m}$ market and nonmarket strategies

Source: the author.

The integrity of the medicine is a key issue in the pharmaceutical industry. Phony products jeopardize the laboratory reputation and brand, in addition of being a crime against the public health. To keep this integrity and preserve its reputation, the company expends huge amounts of resources in the security of products, to ensure that they arrive with no damage at the final destination, which can be a distributor or the government itself.

In Company A, there was a strategic change in the formulation of nonmarket strategies regarding piracy at the end of 2010, due to the company's need to maximize resources and accumulate knowledge about the operations of international gangs operating in the whole world. Also because of the personal security of collaborators, the company has changed the strategy adopted, and started to corporately centralize all the issues regarding piracy in the corporation.

To optimize the resources we have, a specific work group was created in the parent company to do all the actions of our products in the whole world. It only uses the subsidiaries to implement some actions and collect some information to 
allow an improved planning. (Interview with the legal manager of Company A, $2011)^{2}$

Of the three cases studied, we have observed that:

a) The integration of market and nonmarket strategies occurs within the international sphere, and there are specialists on piracy who help formulating anti-falsification strategies, reporting them to the Global Legal area;

b) Locally, companies implement global strategies, involving the relationship with local repression authorities.

c) Market areas are used as source of information, and are only involved in nonmarket strategies related to piracy in the event of an occurrence. Some companies use specialized partners to helm them in the investigation area.

According to Baron (1995a), the interaction between market and nonmarket areas requires that the managers responsible for the market environment are also responsible for the company performance in the nonmarket environment. According to Bartlett and Goshal (1989), nonmarket strategies need to take into consideration the institutions, political issues and configurations existing in the countries where they are located. There were no evidences in the companies researched that in Brazil the pharmaceutical companies manufacturing erectile dysfunction medicines formulate integrated strategies to fight piracy, and that they take into consideration the idiosyncrasies of local institutions. Companies are executors of international strategies that are formulated by a team of international specialists who develop centralized competences to maximize resources in fighting the crime of piracy, which is an international action.

\subsection{Corporate structure for nonmarket strategies}

To analyze the structure, the typology defined by Perlmutter (1969) and Bartlett and Goshal (1989) for multinational companies was used, grouped according to the following items:

1. Internalizes the exploitation of comparative advantages of each country in which it operates, keeping a hierarchical structure, in which the parent company coordinates the activities of all international operations (geocentric).

2 . The creation of strategies would be unilateral, from the parent company to the subsidiaries in order to explore the competitive advantages coming from the parent company itself (geocentric).

3. The subsidiary contributes to the parent company with new skills and knowledge of advanced technology (geocentric);

4. The company keeps integrated operations, with a structure similar to a hub and spoke (global).

\begin{tabular}{|c|c|c|c|c|}
\hline & \multirow[b]{2}{*}{ Company A } & \multirow[b]{2}{*}{ Company B } & \multirow[b]{2}{*}{ Company C } \\
\hline & & & & \\
\hline \multirow{4}{*}{$\begin{array}{l}\text { Structure } \\
\text { for piracy } \\
\text { support }\end{array}$} & $\begin{array}{l}\text { Internalizes the exploitation of comparative } \\
\text { advantages of each country in which operates, } \\
\text { and keeps a hierarchical structure in which the } \\
\text { parent company coordinates the activities of all } \\
\text { international operations (geocentric). }\end{array}$ & Yes & $\begin{array}{l}\text { There were no evidences. Company } \\
\text { follows the global strategy called } \\
\text { "Norma } 70 ", \text { which details actions and } \\
\text { precautions in case of falsification. }\end{array}$ & Yes \\
\hline & $\begin{array}{l}\text { The creation of strategies would be, from the } \\
\text { parent company to the subsidiaries to explore } \\
\text { the competitive advantages with origin in the } \\
\text { parent company (geocentric). }\end{array}$ & Yes & $\begin{array}{l}\text { There were no evidences. The parent } \\
\text { company has created rules for the piracy } \\
\text { fighting process, but with focus on the } \\
\text { security of the product. }\end{array}$ & Yes \\
\hline & $\begin{array}{l}\text { The subsidiary contributes to the parent } \\
\text { company with new skills and advanced } \\
\text { technology knowledge (geocentric). }\end{array}$ & $\begin{array}{l}\text { Yes, through } \\
\text { outsourced } \\
\text { company }\end{array}$ & $\begin{array}{l}\text { There were no evidences. Norma } 70 \\
\text { was created by the parent company to } \\
\text { the whole world, specifying rule by rule } \\
\text { how falsification should be addressed. }\end{array}$ & $\begin{array}{l}\text { Yes, through } \\
\text { outsourced } \\
\text { company }\end{array}$ \\
\hline & $\begin{array}{l}\text { Company keeps integrated operations and with a } \\
\text { structure similar to a "hub and spoke" (global). }\end{array}$ & $\begin{array}{l}\text { There were } \\
\text { no evidences }\end{array}$ & $\begin{array}{l}\text { Yes, there is a small team in the whole } \\
\text { world that implements the Norma } 70 .\end{array}$ & $\begin{array}{l}\text { There were } \\
\text { no evidences }\end{array}$ \\
\hline
\end{tabular}

CHART 5 - Analysis of data according to the corporate structure to fight piracy

Source: adapted from Perlmutter (1969), and Bartlett and Goshal (1989). 
The structure developed by two of the researched companies shows evidences of having the format of the geocentric company defined by Perlmutter (1969) to fight piracy. With the unilateral creation of strategies, from the parent company to the subsidiaries in order to explore the competitive advantages coming from the parent company itself, the team of specialists is localized.

The Company B shows evidences of a global company, according to Bartlett and Goshal (1989), with integrated operations and strategies defined at the parent company for all the subsidiaries. Locally, the Company B develops competences for investigation.
Evidences show that for the piracy issue, the geocentric structure was selected by the two companies that suffer the bigger impact from piracy - with the creation of unilateral strategies, from the parent company to the subsidiaries - due to the fact of the piracy crime being recent, and the gangs promoting this offense being international, obliging companies to use centralization to create competences and maximize resources. For this reason, the existing structure is centralized and follows the hierarchy to maximize efforts, investments, and obtain a fast knowledge as the response for the quick changes effected by the organized crime as shown in Figure 1.

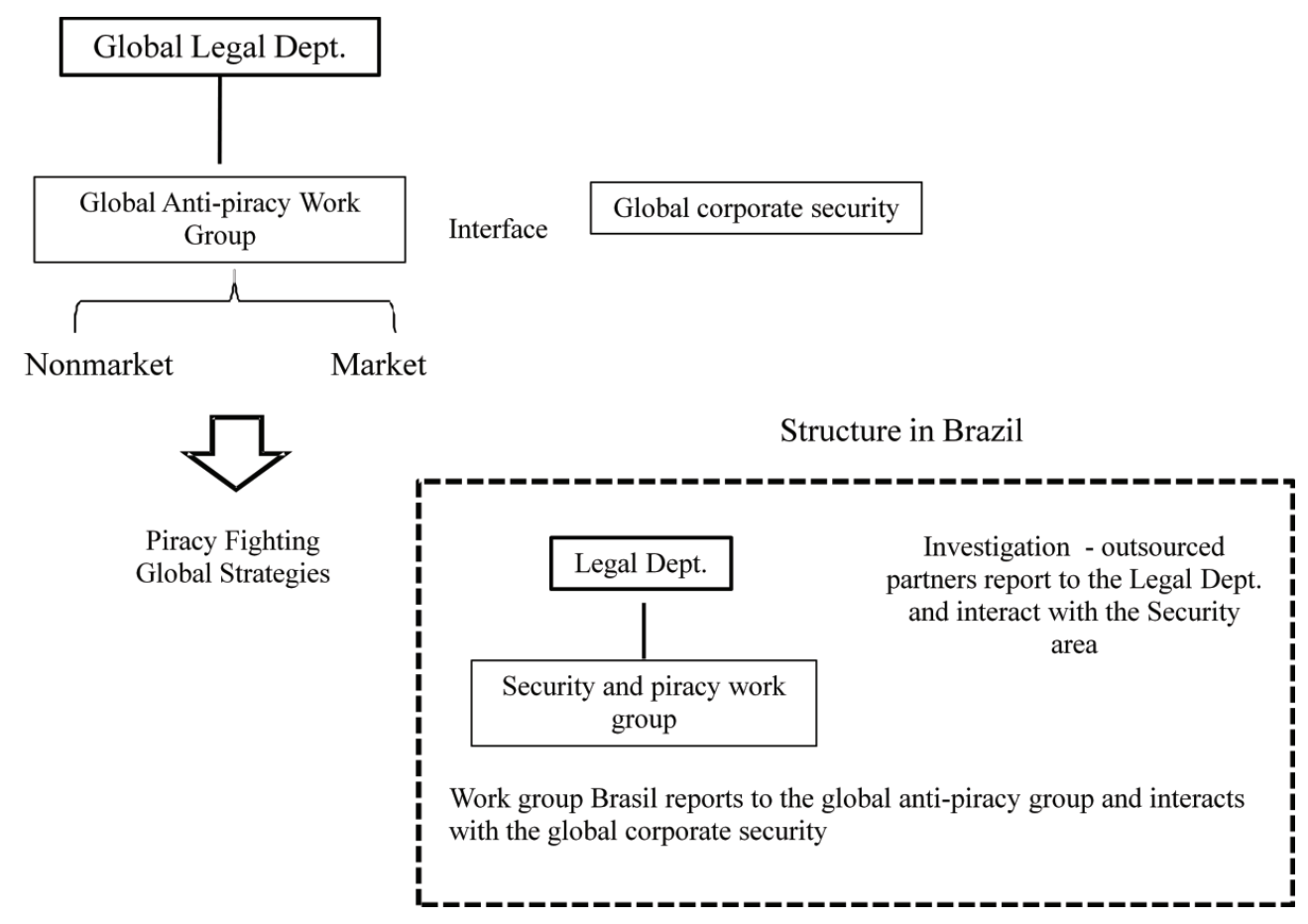

FIGURE 1 - Global structure to fight piracy

Source: the author.

Internationally, the corporate structure dealing with the piracy issue is inserted within the global legal area or the global governmental relations area. To discuss and formulate integrated strategies, the researched companies have created work groups that integrated the market and nonmarket areas. In such structure, we find the specialists that follow up the operations of the organized crime gangs operating globally. Such specialists lead the investigations, make contacts with the international polices, and keep an integrated work with the global corporate security team, which has its own strategies to ensure the security and integrity of medicines worldwide.

The corporate security area takes part in the international group, but has its specific responsibilities of product security, which are fundamental for the area of medicines, because attempting against the human health is a hideous crime everywhere in the world. Furthermore, 
measures for the product security preserve the reputation of the company.

In specific cases, due to the contacts with authorities or to a better understanding of countries where the phony product is in transit, the investigation is done by the global security team interacting with the international group of piracy fight or with the local security area. Companies suffering the bigger impact from piracy reinforce the small local team, contracting partners specialized in investigation and apprehension, who interact with the local group or with the international group. In the case of Company A, there is no longer a local structure, and for regarding the security of its employees as fundamental, the company has decided to outsource the job. The total outsourcing is not guided by exclusively economic factors, confirming Hillman and Hitt (1999).

As a matter of fact, we don't have a dedicated structure in the subsidiary, there are only some people in specific areas who are contact points for information and to make some local arrangements. [...] To optimize the resources of the subsidiaries, the parent company staff does everything, and we only help. (Interview with the legal manager of Company A, 2011) ${ }^{3}$.

The parent company has decided to work with an outsourced office also here in Brazil, specialized in this kid of action. And then, some internal areas of the company, such as the legal dept. and the quality control staff, provide some kind of support only in contacting people, but there is a specialized external office that will do the actions determined by this group of the parent company. (Interview with the legal manager of Company A, 2011). ${ }^{4}$

In case of piracy, two multinational companies showed evidences of having a geocentric structure of the parent company/ subsidiary relation as defined by Perlmutter (1969). The main objectives of this choice are to accumulate knowledge and maximize resources. Only one of the companies keeps a global structure (BARTLETT; GOSHALL, 1989). This difference can be explained by the impact piracy causes to companies When it is big, companies centralize - geocentric structure - to be able to act fast with the available resources, and to develop new competences, since the organized crime is agile and is constantly changing its modus operandi. When the impact of piracy is small, the global strategy defines procedures to fight it, using the security team or outsourced partners.

\subsection{Nonmarket activities}

The political activities confirmed by more than one source were grouped according to the model of approach, participation and strategic decision-making (HILLMAN; HITT, 1999).

\begin{tabular}{|c|c|c|c|c|}
\hline Strategies & & Company A & Company B & Company C \\
\hline \multicolumn{5}{|c|}{ Transactional strategies } \\
\hline Information & $\begin{array}{l}\text { Individual - } \\
\text { actions related } \\
\text { to the owner } \\
\text { of the patent }\end{array}$ & $\begin{array}{c}\text { Actions of apprehension and } \\
\text { investigation (outsourced } \\
\text { company). Federal and state } \\
\text { polices. Highway police. Institute } \\
\text { of criminalistic. ANVISA. }\end{array}$ & $\begin{array}{c}\text { Actions of apprehension and } \\
\text { investigation (outsourced } \\
\text { company). }\end{array}$ & $\begin{array}{l}\text { Actions of apprehension } \\
\text { and investigation. } \\
\text { Federal and state polices. } \\
\text { Highway police. Federal } \\
\text { Revenue. }\end{array}$ \\
\hline \multicolumn{5}{|l|}{ Relational strategies $r$} \\
\hline Information & Collective & $\begin{array}{l}\text { Interfarma: educational actions, } \\
\text { seminars and lectures, ANVISA, } \\
\text { Regional Pharmacy Councils. }\end{array}$ & $\begin{array}{c}\text { Interfarma and ABSO: } \\
\text { educational actions, ANVISA, } \\
\text { Regional Pharmacy Councils, } \\
\text { Federal Revenue. }\end{array}$ & $\begin{array}{l}\text { Interfarma and ETCO: } \\
\text { Relationship with the } \\
\text { federal government. }\end{array}$ \\
\hline Financial incentive & Collective & $\begin{array}{l}\text { Interfarma: congressmen trips } \\
\text { to international visits. President } \\
\text { of Interfarma with political } \\
\text { experience. }\end{array}$ & $\begin{array}{l}\text { Actions organized by } \\
\text { Interfarma }\end{array}$ & $\begin{array}{l}\text { Actions organized by } \\
\text { Interfarma or ETCO. }\end{array}$ \\
\hline
\end{tabular}

CHART 6 - Nonmarket activities to fight piracy, according to Hillman and Hitt (1999)

Source: adapted from Hillman and Hitt (1999). 
In case of piracy, there are two types of actions: individual and collective. The individual ones are done with entities operating in the field of human health, such as ANVISA and the Regional Councils of Pharmacy, in which the company individually does the approach and presents information. In case of collective actions, such as repression, actions are jointly carried out through
Interfarma, because of the need of government coordination to mobilize the group of agents in each location. In such cases, the Federal Revenue prefers to meet and to dialogue with professional institutions.

Figure 2 shows the strategic nonmarket activities identified in the research, and that are schematized according to Hillman and Hitt (1999).

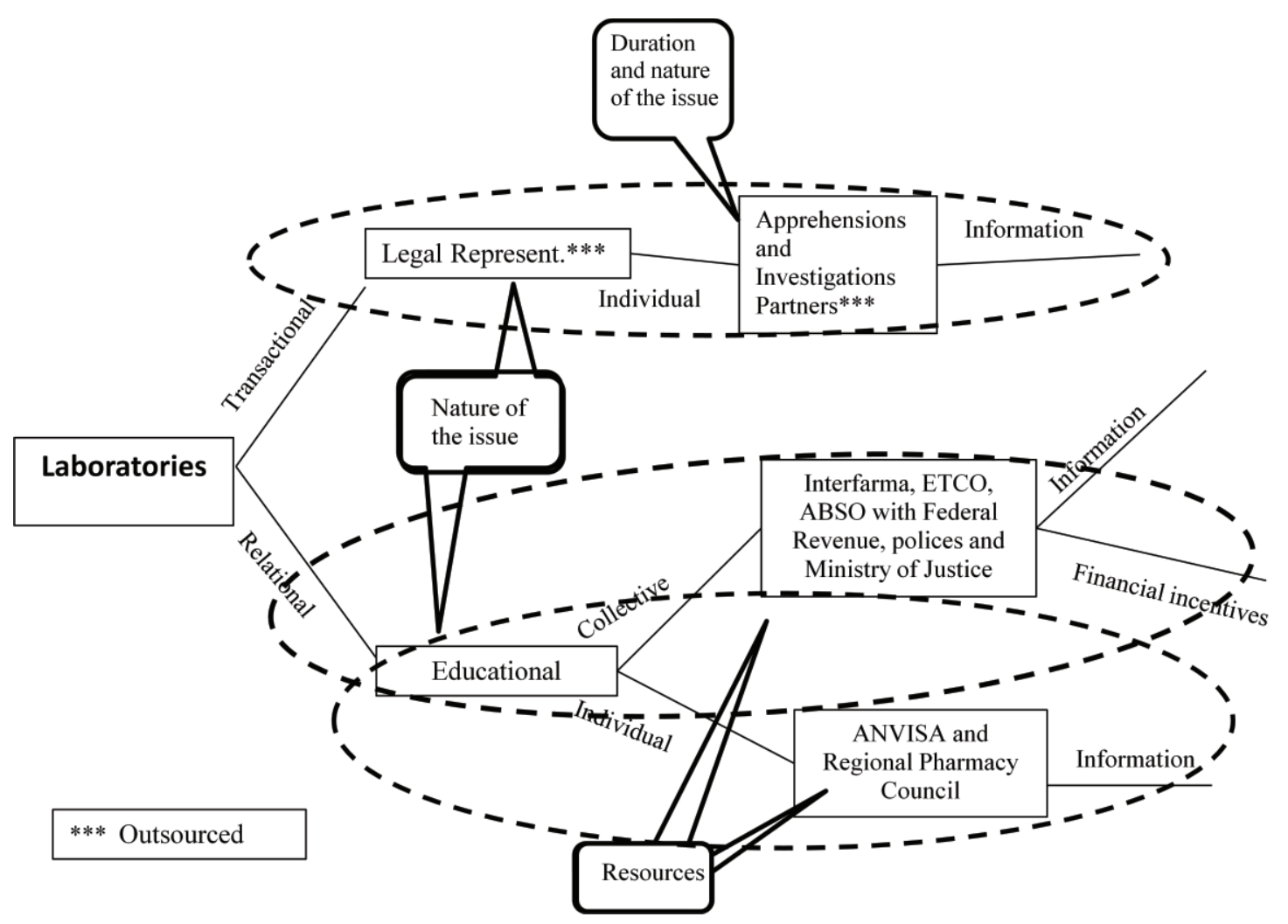

FIGURE 2 - Strategic nonmarket activities

Source: adapted from Hillman and Hitt (1999).

Boddewyn and Brewer (1994) define that the political behavior of international companies is affected by the differences of institutional environments where they invest. Rufin, Parada and Serra (2008) confirm in the study on emerging countries that one of the backgrounds of nonmarket strategies of companies investing in emerging countries is the institutional environment of the origin country and of the host country. Hillman and Hitt (1999) analyze the nonmarket strategies in countries with corporatism or pluralistic systems, and propose that in countries where power is centralized, companies would rather use collective strategies. Chaudhry et al. (2009) observe that multinational companies investing in countries where their managers perceive a high level of piracy adopt tailor-made actions, differentiated per country. The main variables affecting the companies' decisions on selecting either a transactional or relational relationship are: 1) the degree in which the company is affected by the public policy; 2) the level of the product diversification; 3) the degree of corporatism/pluralism within the country in which the companies operate (HILLMAN; HITT, 1999). 
In Brazil, the individual political actions are transactional and reactive. The collective ones are relational and proactive. There were no evidences of tailor-made actions, despite the increasing level of piracy in Brazil. The choice for collective actions is related to the preservation of the business reputation of companies, and the political force the group has before institutions. There was no evidence that the choice of collective actions has been done due to lesser financial resources and/or intangible resources, opposed to Hillman and Hitt (1999) say. There was evidence of a strengthening of professional entities, executors of collective activities, by hiring influential former politicians to head such institutions.

\section{DISCUSSIONS AND CONCLUSIONS}

The main objective of this study was analyzing how the strategic management process of multinational pharmaceutical industry companies occur - more specifically of erectile dysfunction medicine makers - that operates in the Brazilian market, and suffer from the impact of piracy, analyzing whether such companies adopt market and nonmarket strategies in an integrated manner, checking which organizational structure support the integration, and which are the piracy fight activities adopted by the companies locally. Observing the three research propositions (item 2.3), we realize that there are no evidences of the existence of the strategic integration in Brazil. Therefore, proposition 1 was not confirmed.

Internationally, multinational medicine making companies integrate their market and nonmarket strategies by means of work groups existing in the corporate structure, sustaining the model of Baron (1995a). Evidences show that companies suffering the higher impact of piracy use the geocentric structure with centralized nonmarket strategies, formulated in the parent company to maximize resources and create new competences. Therefore, proposition 2 was not confirmed.

When the impact of piracy is still small, global strategies, which are executed by specialized outsourced companies, are used. The partial or total outsourcing of the investigation area is the choice when the personal security of collaborators is at stake.

The pharmaceutical industry in Brazil is very much regulated, and thus it greatly depends on governmental policies. Companies working in the industry use the relational approach to design their political actions. To dialogue with governmental repression institutions, there is the need of coordinated collective actions, and the individual participation as a way of political action was not evidenced by the results found. Such actions are not more likely chosen by companies with financial resources and/or intangible resources as defined by Hillman and Hitt (1999). Collective actions are more used by companies, mostly because of their political influence - some of them are headed by former politicians with remarkable political relationships. With this, proposition 3 was confirmed.

Companies makers of erectile dysfunction drugs use collective actions to work with the Brazilian government with the aim of reducing the impact of institutional arrangements that facilitate piracy. Through professional entities - Interfarma, the most mentioned one, and ETCO - associated companies promote activities to provide information and to financially stimulate governmental representatives and agents. The objective of such initiatives is to increase the knowledge of governmental agents, as well as to mobilize the society, highlighting the harms of piracy to the economy and to the health of people. Business associations with more political force or those operating in higher spheres of the government are those responsible for this type of activity.

Locally, the nonmarket strategies still have little interaction with market-based strategies. In their countries of origin, companies make the integration of these two types of strategies through work groups or formal corporate structures, reporting to the vice-presidency level. The focus here in Brazil is the investigation. Companies receive global strategies formulated in the parent company, and execute them directly or via third parties. 
Opposed to the theories previously studied, such as Chaudhry et al. (2009) that observes that the EMNs that invest in countries where their managers perceive a high level of piracy adopt tailor-made actions specific per country; i.e., the piracy fighting management in pharmaceutical companies is centralized, with little local autonomy, and little integration with market activities. Some explanations for this fact that should be investigated are: 1) maximization of resources - higher investment in preventive actions, such as product security, and lesser investment in investigational actions, related to piracy; 2) personal security of the collaborators of local pharmaceutical companies, involved in the fighting actions, who are threatened by the organized crime; 3) definition of piracy as a global issue, with local impact, which thus need to have global strategies with local actions.

Two management recommendations for the researched companies based on Pearce (2001): 1) to increase the flow of information between companies and institutions, to be more agile in repressing and to increase the degree of influence. 2) to structure the nonmarket activities along with other sectors to increase the political impact on other spheres of government, such as the legislative and the judiciary powers.

Specialized entities can develop multisector strategies that supplement, reinforce or make the market strategies of companies possible. Entities can be the leading roles in the development of more lasting personal relationships with the institutions, and develop competences and capacities that can support the international areas of the associated companies that formulate global strategies.

In regard to the organizational structure, it is noteworthy that the complexity and continuous changes that occur in the Brazilian government, at each four years due to the presidential elections, and within the institutions themselves, cause important transformations in such institutions. It would be recommendable that companies kept a minimum structure dedicated to piracy fighting, to locally develop specific competences related to the issue. An area with future developments is to deepen the knowledge on selecting the structure to address the issue of piracy - geocentric or global, in terms of effective maximization of resources and creation of new competences.

In regard to the theoretical model presented by Hillman and Hitt (1999), it would be important to check how the strengthening of business institutions through their presidents interferes with the selection of collective actions adopted by companies.

This study was conducted with a limited market segment, represented by multinational companies makers of erectile dysfunction drugs, with distinct peculiarities. However, piracy is a misfortune affecting many sectors, indistinctly, and from this viewpoint, the observations and recommendations herein presented could be extended to other segments, especially for the nonmarket strategies, since the governmental institutions are almost all the same.

We should highlight that successful nonmarket strategies adopted by some segments could be extended to others. Not to mention the multi-sector collective actions that could cause a bigger impact on the government and to the society.

\section{NOTAS}

1. We point out that the parts of interviews to be presented throughout this article will not have the names of the interviewees revealed for ethical reasons and to keep confidential the identity of each of them, due to the commitment undertaken during the conduction of the research.

2. Idem nota anterior

3. Id. note 1

4. Id. note 1

\section{REFERENCES}

AGÊNCIA NACIONAL DE VIGILÂNCIA SANITÁRIA (BRASIL) - ANVISA. Reunião da Comissão de Assuntos Sociais. Conjunta com a $1^{\text {a }}$ Reunião da Subcomissão Permanente de Promoção, Acompanhamento e Defesa da 
Saúde, da 4a Sessão Legislativa Ordinária, da 53a Legislatura, Brasília, Congresso Nacional, Audiência pública realizada em 25 de fevereiro de 2010. Disponível em <http://www.senado.leg. br/Relatorios_SGM/RelPresi/2010/011.03-SFREL2010-CAS.pdf>. Acesso em: 27 maio 2013.

BARON, D. P. Integrated strategy: market and nonmarket components. California Management Review, Berkeley, v. 37, n. 2, p. 47-65, Winter 1995a.

The nonmarket strategy system. Sloan Management Review, Cambridge, v. 37, n.1, p. 73-85, Fall 1995b.

BARTLETT, C. A.; GHOSHAL, S. Managing across borders: the transnational solution. Boston, Mass: Harvard Business School Press, 1989.

BODDEWYN, J. J. Understanding and advancing the concept of "nonmarket". Business $\&$ Society, Thousand Oaks, v. 42, n. 3, p. 297-327, Sept. 2003.

; BREWER T. L. International business political behavior: new theoretical direction. Academy of Management Review, Briarcliff Manor, v. 19, n.1, p. 119-143, Jan. 1994.

CHAUDHRY, P. et al. Evidence of managerial response to the level of consumer complicity, pirate activity, and host country enforcement in counterfeit goods: an exploratory study. Multinational Business Review, St. Louis, Bradford, v. 17, n. 4, p. 21-44, 2009.

GIGLIO, E. M.; RYNGELBLUM, A. L. Uma investigação sobre o ator consumidor na rede de pirataria e uma proposta de alternativa de estratégia de combate. RAM - Revista de Administração Mackenzie, São Paulo, v. 10, n. 4, p. 131-155, jul./ago. 2009.

GOPAL, S. B. R. D.; LERTWACHARA, K.; MARSDEN, J. R. Consumer search and retailer strategies in the presence of online music sharing.
Journal of Management Information Systems, Armonk, v. 23, n. 1, p. 129-159, Summer 2006.

HARZING, A. W. An empirical analysis and extension of the Bartlett and Goshal typology of multinational companies. Journal of International Business Studies, Newark, Basingstoke, v. 31, n. 1, p. 101-120, Mar. 2000.

HILLMAN, A.; HITT, M. A. Corporate political strategy formulation: a model of approach, participation and strategy decisions. Academy of Management Review, Briarcliff Manor, v. 24, n. 4, p. 825-842, Oct. 1999.

IYENGAR, D. et al. Parameters for software piracy research. The Information Society, Philadelphia, v. 24, n. 4, p. 199-218, 2008.

KARIITHI, N. K. Is the devil in the data? A literature review of piracy around the world. The Journal of World Intellectual Property, Geneva, Oxford, v. 14, n. 2, p. 133-154, Mar. 2011.

KEIM, G. Foundations of a political strategy for business. California Management Review, Berkeley, v. 23, n. 3, p. 41-48, Spring 1981.

KHANNA, T.; PALEPU, K. The future of business groups in emerging markets: long-run evidence from Chile. Academy of Management Journal, New York, v. 43, n. 3, p. 268-285, June 2000.

LAGRECA, R. H.; HEXSEL, A. Concorrência desleal: concepçóes do processo de mobilização estratégica a partir de um estudo de caso. RAC - Revista de Administraçáo Contemporânea, Rio de Janeiro, v. 11, ed. especial, p. 11-31, 2007.

MAHONEY, J. T.; CHI, T. Business Strategies in Transition Economies. Academy of Management Review, Thousand Oaks, v. 26, n. 2, p. 311-313, Apr. 2001.

MARIOTTO, F. L. Estratégia internacional da empresa. São Paulo: Thomson, 2007.

MILLER, S. R.; BOVE, C. R. Fighting intellectual property theft in the internet age: why we need 
a statute like the combating online infringement and counterfeits. Intellectual Property \& Technology Law Journal, [s. 1.], v. 23, n. 4, p. 3-11, Apr. 2009.

NORTH, D. C. Institutions, institutional change and economic performance. Cambridge: The Press Syndicate of the University of Cambridge, 1990.

PEARCE, J. L. How we can learn how governments matter to management and organization. Journal of Management Inquiry, Thousand Oaks, v. 10, n. 2, p. 103-112, June 2001.

PERLMUTTER, H. The tortuous evolution of the multinational corporation. Columbia Journal of World Business, Oxford, v. 5, n. 1, p. 9-18, 1969.

RUFIN, C.; PARADA, P.; SERRA, E. O paradoxo das estratégias multidomésticas num mundo global: testemunho das estratégias de "não mercado" nos países em desenvolvimento. RBGN - Revista Brasileira de Gestão de Negócio, São Paulo, v. 10, n. 26, p. 63-85, 2008.

RYNGELBLUM; A. L. Influências 'heterorracionais' sobre as organizações e seu tratamento pelas teorias de estratégia: o caso da pirataria. RAC - Eletrônica, Rio de Janeiro, v. 1, n. 2, p. 66-80, maio/ago. 2007. Disponível em: <http://anpad.org.br/periodicos/content/ resumos.php? revista_id=3\&artigo_id=636>. Acesso em: 27 maio 2013.
SINHA, R. K.; MACHADO, F. S.; SELLMAN, C. Don't think twice, it's all right: music piracy and pricing in a DRM-free environment. Journal of Marketing, Chicago, v. 74, n. 2, p. 40-54, Mar. 2010.

SMITH, M. D.; TELANG, R. Competing with free: the impact of movie broadcasts on DVD Sales and internet piracy. MIS Quarterly, Minneapolis, v. 33, n. 2, p. 321-338, June 2009.

WOOLLEY, D. J. The cynical pirate: how cynicism effects music piracy. Academy of Information and Management Sciences Journal, v. 13, n. 1, p. 31-[44], Jan. 2010.

WORLD HEALTH ORGANIZATION WHO. Combating Counterfeit Drugs: Building Effective International Collaboration. 2006. Disponível em: <http://www.who.int/medicines/ events/FINALBACKPAPER.pdf $>$. Acesso em: 27 maio 2013.

YANG, D. et al. Global software piracy: searching for further explanations. Journal of Business Ethics, Dordrecht, v. 87, n. 2, p. 269-283, June 2009.

YOFFIE, D. B. Corporate strategies for political action: a rational model. MARCUS, A. A.; KAUFNIAN, A. M.; BEAM, D. R. (Eds.). Business Strategy and public policy: perspectives from industry and academia. New York: Quorum Books, 1987. p. 43-60. 